\title{
Post-harvest preservation of roses cv. Ipanema
}

\author{
Simone Lyn Van Oene ${ }^{1}$, Claudia Fabrino Machado Mattiuz ${ }^{1}$, Tauane Santos Brito ${ }^{2}$ and Renan Pan ${ }^{2 \star}$
}

\author{
${ }^{1}$ University of São Paulo, Piracicaba, SP, Brazil. \\ ${ }^{2}$ State University of Western Paraná, Marechal Cândido Rondon, PR, Brazil. \\ *Author for correspondence: renanpan45@hotmail.com
}

OPEN ACCESS

(c) The Authors

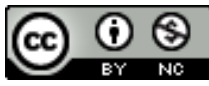

Submitted on July 02, 2019 Accepted on August 20, 2019 Early View on August 26, 2019 Final Publication on August 28, 2019

Authors declare no conflict of interest KEYWORDS: Rosa sp. Cut flowers Flower shelf life Flower pot life

\section{ABSTRACT}

Roses are highly perishable cut flowers that demand an adequate post-harvest management seeking the maintenance of quality and reduction of post-harvest losses. Among the most used manipulations, stand out the complete cold chain, as in the producer as in the transport and storage in Garden centers, supermarkets and flower shops, besides, it can be mentioned as the most important management the use of conserving solutions, which have been proving increasingly important for the maintenance of longevity and quality. The objective of this study was to evaluate three product lines offered by the Chrysal Premium Flower Care ${ }^{\circledR}$, which has different functions and must be used in the three stages of the cut roses chain, post-harvest, transport/storage and final consumer. During the study was considered the real farm logistic, harvest, storage, transport, sale to wholesaler "and purchase by the final consumer, in a way to approximate the producer from the result of the study and show in a practical way the efficacy of the use of conserving solutions for the maintenance of cut roses. The experiment had five treatments with two replicates each, the evaluations were carried until the end of the flower's shelf life and consisted in: turgescence, bent neck, petals darkening, flower opening, fresh mass evaluation and water absorption. It is concluded that the operations of harvest and transport are of crucial importance in the maintenance of the longevity and quality of roses, however, it must be allied to an adequate post-harvest treatment, the investment takes the producer to opt to not use or use only one preservative. It was also concluded that the postharvest treatment is the most indicated increasing the pot life of the stems when compared to other treatments.

\section{Highlighted Conclusions}

1. Harvest and transport operations essential for maintenance of longevity and quality of roses.

2. Operations of harvest and transport of roses must be proceeded by an adequate postharvest treatment.

\section{INTRODUCTION}

Flower longevity is determined by pre-harvest and post-harvest factors and it is also related to genetic and anatomic characteristics of each specie cultivated. As pre-harvest factors, it can be mentioned maturation stage, crop shading and cultivar as for post-harvest factors the storage temperature, air moisture, luminous intensity among others (Nowak and Rudnicki 1990). Roses generally have a limited storage lifespan, requiring some techniques to prolong the flowers durability such as the use of preservative solutions, being the most used solutions constituting of germicides, phytoregulators and sugars (Diastagliacozzo and Castro 2002).

The quality aspect of flower production is defined by a set of attributes that make the product easier to sell. For cut flowers these characteristics are: size, shape and condition (sanity, turgescence and maturity). The time in the year where the product is harvested and commercialized depends directly from the demand, because, many times, the feedstock stay stored for a long time, compromising their quality characteristics (Castro 1993). During the postharvest commercialization chain, the flowers can suffer different kinds of stress, such as inadequate temperature, dehydration and mechanical damage that compromise the aesthetic quality and reduce their longevity and can be influenced by the action of ethylene (Woltering and Van Doorn 1988; Macnish et al. 2010).

Flowers deteriorate similarly to fruits and vegetables by means of physiological processes (Hardenburg et al. 1990). Among them, the respiration that causes the exhaustion of tissue reserves, mainly carbohydrates. Cold 
storage is extremely effective to reduce respiration, preserving carbohydrates and reserves and prolonging the flower's life (Fischer 1953; Siegelman, 1952; Halevy and Mayak 1974). Each specie has a specific lifespan for the flower, being it carefully adapted to the ecological exigencies (Rogers 2006).

The use of preserving solutions to keep quality and prolong the lifespan of cut flowers has evolved in the past few years, being this a recurring practice in countries where flowers represent a major source of resources. Normally there are four kinds of solutions used, which can be classified as conditioning solutions, pulsing solutions, solutions to induce flower opening and maintaining solutions (Castro 1993).

A conserving solution has for their functions: the supply of carbohydrates used during respiration, reduction in ethylene production, which is responsible for the flower senescence, bactericidal effect by the acidification of the medium, for suspension of bacterial growth and break of water superficial tension, making its absorption easy for the flowers (Oliveira 1995).

The components of conserving solutions allow the flowers to keep their quality along all the commercialization process. The amount of each component depends on the time of absorption of the flower (Oliveira 1995).

Against the foregoing, this research aimed to evaluate three post-harvest treatments from the Chrysalß brand to increase quality of rose Ipanema cultivated in a protected environment.

\section{MATERIAL AND METHODS}

Place description. The experiment was carried out in two places, at the farm of the producer Adriano Van Rooyen located in Holambra - SP, where the roses were harvested and at the test center of the Holambra Veiling Cooperative, located in the town of Antonio da Posse, for the evaluation of the treatments and the flower pot life.

Plant material. Were used roses from the Ipanema variety (red color), cultivated in greenhouses. The plants were harvested in September, with an average temperature of $22^{\circ} \mathrm{C}$ at harvest time (7:00 a.m.) according to the farm's logistic. This cultivar was chosen due to its great market value, by its red color that is very appreciated and also because it has problems with Bent Neck.

Chemicals. Were used three products provided by Chrysal ${ }^{\circledR}$ which are recommended for maintenance in roses post-harvest. The "Chrysal® inicial" (Aluminum sulfate $25-50 \%$, Di-hydrate of dichloride cyanurate of sodium) indicated for packaging, the Chrysal professional T-bag® (Citric acid 10-25\%, 2 Octil-2H-Isotiozol-3ona < 0.05\%) indicated for transport and the Chrysal Universal clearß (Citric acid $>2.5-5 \%$ ) indicated for the final customer.

Experimental design. The experiment was carried out in a completely randomized design, with five treatments and two replicates per treatment totalizing 100 rose stems for the cultivar Ipanema.

Treatments and solutions. Each solution has its own time of preparing determined by the supplier Chrysal ${ }^{\circledR}$ Premium flower care. The time used in this experiment simulates the minimum time for each stage (Table 1).

For the first stage the "Chrysal ${ }^{\circledR}$ Inicial" (post-harvest) was used, with a minimum duration of 4 hours, determined by the company, essentially for recently harvested roses to rehydrate and to clean the pots after the cut. For the second stage was used the Chrysal Professional 2 T-bag ${ }^{\circledR}$ (packaging and transport), with a minimum duration of 96 hours, determined by the company and consumers, as the minimum time of transport from the farm to the Veiling, sale to the wholesaler, distribution of the roses along supermarkets or floricultures and purchase by the final consumers.

Last, the third stage used the product Chrysal Universal Clear® (final consumer), used from the moment where the roses are transferred to the pots until the closure of decorative life. The commercial sachet is sent with the bundles of roses to help maintain them viable for longer. Using the sachet, makes unnecessary to change the water.

Temperature and used water. The water temperature was monitored during all the post-harvest stages, including the services barn, cooler, transport until the Veilign and packaging in the cooperative test center, with the TAG. The water on the farm had a pH 7.0 while the one from the test center had a pH 8.2.

Weighing the samples. Two weighs were made, the first one right after harvest, removing basal leaves and standardizing a $60 \mathrm{~cm}$ cut, being considered the initial weigh in the fresh mass calculation. The second weigh was made after 4 hours of stage I, first water. When the stems from the first water were transferred to the bins with the treatments for the stage II, this weigh showed how much the stems absorbed from the initial solution, being it Chrysal inicial@ or water.

The following weighs were performed every two days, determining the harvest day as day 1 . The weighs were made until the last day of decorative life of the pots, the water remaining in the pot was also measured for the obtainment of absorption data and visual evaluation of water turbidity.

Cut and cleaning of stems and basal leaves. Two cuts and two cleanings were made in the flower stems. The first was made right after harvest, to prepare and standardize the bundle size as it is made commercially. The 
second was in the center of tests to prepare the samples to go to the test pots, this operation simulates the final consumer, which acquire the bundle, cuts about $1.5 \mathrm{~cm}$ of the stem, clean leaves in excess and transfer them to a pot.

Table 1. Stablished stages for the experiment. Each stage represents a sector of the productive chain, being stage 1 the post-harvest, stage 2 packaging and transport and stage 3 the final costumer.

\begin{tabular}{|c|c|}
\hline Treatment & Description \\
\hline 1 & Flower stems stored in water during all the experiment (Control) \\
\hline 2 & $\begin{array}{l}\text { Flower stems treated with "Chrysal } \circledast \text { inicial" in the first four hours of treatment. Then the stems were placed } \\
\text { in a bin with water and stored in the farmer cooler for } 24 \text { hours. After the } 24 \text { hours in the cooler, the roses } \\
\text { were transported to the Veiling and stored for more } 72 \text { hours in the cooler in the test center. After this period, } \\
\text { finalizing the four days of treatment of stage } 2 \text {, the roses were transferred to pots with water and kept in } \\
\text { them until the end of their decorative life. }\end{array}$ \\
\hline 3 & $\begin{array}{l}\text { Flower stems treated with conserving solution "Chrysal }{ }^{\circledR} \text { Inicial" for four hours, then treated with Crhysal } \\
\text { Professional } 2 \text { T-Bag }{ }^{\circledR} \text { for four days. After } 24 \text { hours in the farmer's cooler the roses were transported to the } \\
\text { Veiling and stored for more } 72 \text { hours. By the end of four days of treatment of stage } 2 \text { the roses were } \\
\text { transferred to pots with water and kept in them until the end of their decorative life. }\end{array}$ \\
\hline 4 & $\begin{array}{l}\text { Flower stems treated with just water in the first four hours, then the stems were treated with conserving } \\
\text { solution Chrysal Professional } 2 \text { T-Bag® for four days. After } 24 \text { hours in the farmer's cooler the roses were } \\
\text { transported to the Veiling and stored for more } 72 \text { hours in the test's center cooler. By the end of four days of } \\
\text { treatment of stage } 2 \text { the roses were transferred to pots with water and kept in them until the end of their } \\
\text { decorative life. }\end{array}$ \\
\hline 5 & $\begin{array}{l}\text { Flower stems treated with conserving solution "Chrysal Inicial®" for four hours, then treated with Chrysal } \\
\text { Professional } 2 \text { T-Bag® for more four hours. After } 24 \text { hours in the farmer's cooler the roses were transported } \\
\text { to the Veiling and stored for more } 72 \text { hours in the test's center cooler. After } 72 \text { hours, ending the four days of } \\
\text { treatment of stage } 2 \text {, the roses were transferred to pots with Chrysal Universal Clear } \circledast \text {, the commercial } \\
\text { sachet, and kept in until the end of their decorative life. }\end{array}$ \\
\hline
\end{tabular}

Sampling time. The essay was performed in September, a time where, due to the heat, the rose production normally is affected. However, during the harvest day the average temperature was of $21^{\circ} \mathrm{C}$ and the moisture was of $55 \%$, considered uncommon for this time of the year in the region. The harvest point was the same as the ones for commercial purposes, established by the farmer, as the one in Figure 1.

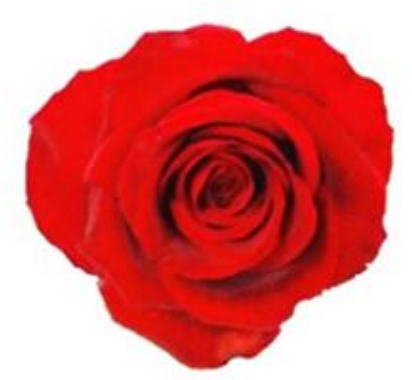

Figure 1. Harvest point used.

The roses were manually harvested, during the morning, cutting the base of the stems with pruning shears. Generally, harvesting during the fresh times of the day, keep roses tissues turgid, offering a greater resistance to the stress suffered during harvest.

Seeking to make the experiment as near as possible to the farmers condition, the entire experiment was carried following the logistic of the farm, to do so the harvest was made together with the employee of the farm. The first 20 stems were harvested, cleaned the basal leaves and cut in $60 \mathrm{~cm}$, weight and placed in a bin with the respective treatment. This was repeated for all the next 80 stems, respecting the maximum time limit between harvesting and transfer to the first water (10 min).

After harvest, the bins containing the flower stems were forwarded to the services barn and then for the cooler of the farm. The roses were cool until $5{ }^{\circ} \mathrm{C}$ (average temperature of coolers of farmers) and kept there for four hours. These four hours represent, inside the farm logistic, the time of harvest and preparation of all the roses that will be sold in the Veiling.

All plants were transported 24 hours after harvest, the bushel bins were transported together with the roses that were sold in the Veiling in a refrigerated container. The trip until the Veiling and the discharge lasted 30 minutes, with an average temperature of $10^{\circ} \mathrm{C}$. 
Transference of flowers into pots. The last stage of the experiment, which consisted in transferring the flowers to test pots which represents the final consumer, is the most important since all the data gathered in this period are used to evaluate the pot life for the final consumer. At this stage it can also be observed the influence of each stage and their respective treatments has on established longevity and roses ratings.

The transfer of the roses to the test pots was made while removing the bins from the cooler one by one. First the bundles were separated, with 10 stems each, for the division of the treatment's replicates. The 10 stems were weighted and then cut $1.5 \mathrm{~cm}$ of the base and removed the base leaves. Next, was made another weigh. This procedure was made for all the roses of the experiment. Then, with all treatments ready, the pots were placed on a table in the test center to do the evaluation until the final decorative life of the stems.

Evaluations. The evaluations were monitored until the flowers were considered without the necessary patterns for maintenance of qualitative characteristics.

The accumulated fresh mass (gain or loss) calculation of the inflorescences was calculated by subtracting, on each day of evaluation, the value of the mass of the respective day of the mass obtained in the previous evaluation. The variation values were transformed in percentage and added to the previous values. Only for this evaluation the data were submitted to variance analysis by means of the $F$ test, and the means compared with the Tukey test at $5 \%$ of probability.

Qualitative analyzes were done daily with assignments of notes (Figures 2, 3, 4 and 5) that began on the day of stem pot life until the closure of the decorative life, that is, when they are not feasible for commercialization. For determination of commercial infeasibility, a standard was set where $50 \%$ of the stem blossoms were wilted. Longevity was assessed along with visual analyzes.
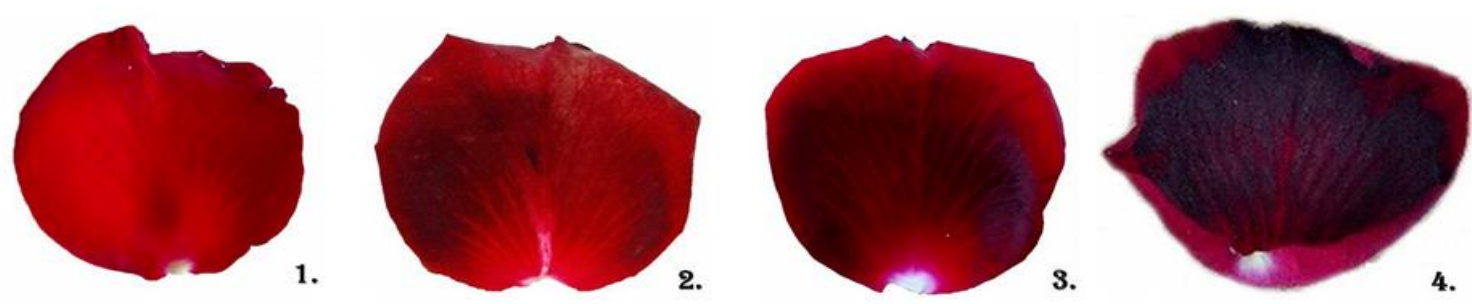

Figure 2. Pre-established notes for petal darkening. Without darkening (1). Light darkening (2), moderate darkening (3), intense darkening (4).
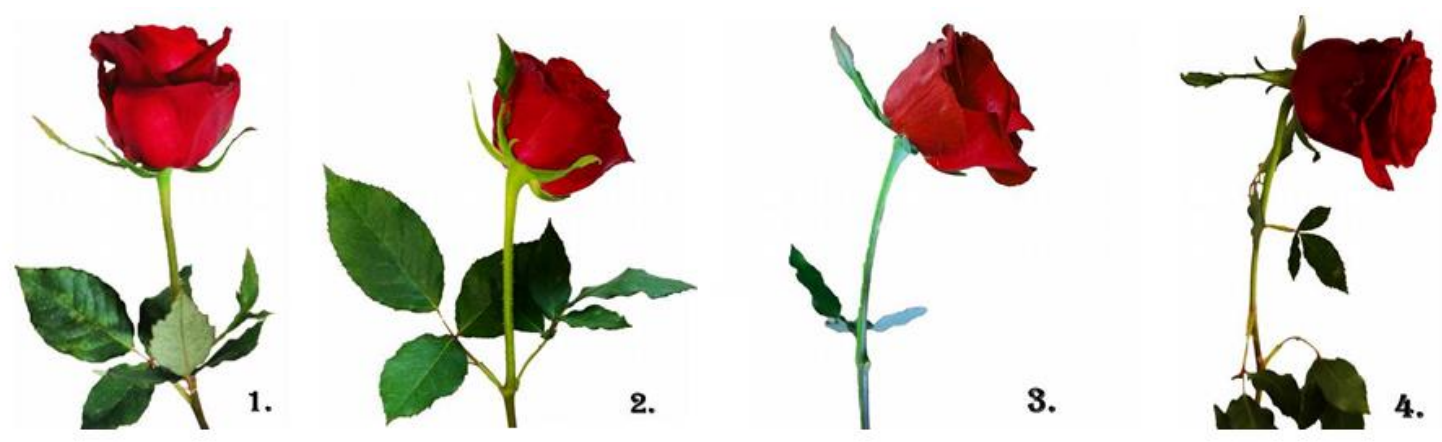

Figure 3. Preestablished notes for the Bent Neck evaluation. Caption: without bending (1), beginning of bending (2), medium bending (3), serious bending (tipping) (4).

Qualitative aspects were defined according to the following criteria through the assignment of notes. The parameters to characterize and determine the longevity of the cut rose are according to Zieslin and Gottesman (1983), the yellowing of sepals; the wilt, the blueness and the abscission of the petals; the failure to open the buttons and the neck fall, being the metabolic factor that most affects it and the flow of water in the wooden vessels. The post-harvest life of roses usually comes to an end due to the loss of stem rigidity, known as a neck drop, a phenomenon that is associated with water loss and insufficient lignification.

Stems must be straight and strong enough to hold the flowers, which are normally heavy, being their length the main parameter of quality for the evaluation of some cut flowers. However, there is always necessary an equilibrium between the flower size and stem length, which is a very subjective balance, since problems with the stems, such as curvature in the vicinity of the flower receptacle, can only be observed during post-harvest processes. 


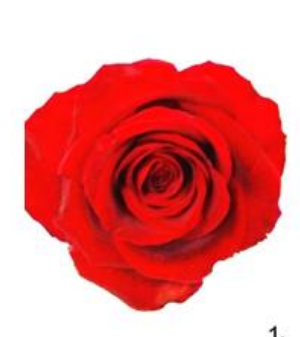

1.
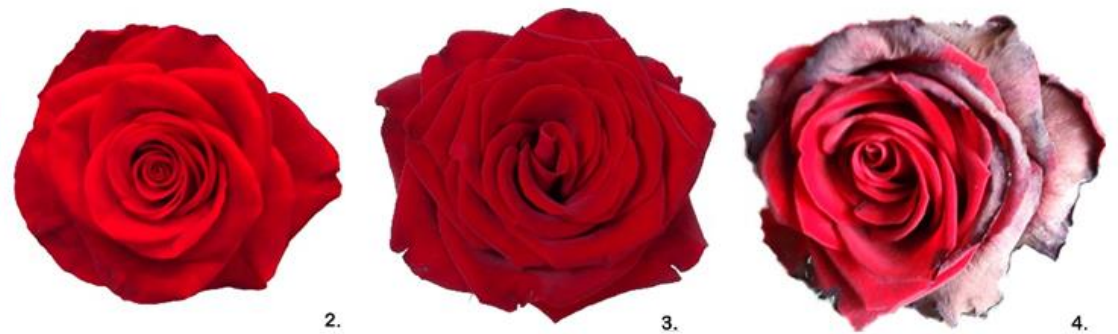

Figure 4. Preestablished notes for the floral opening evaluation. Caption: bud (1), beginning of anthesis (2), anthesis (3), total opening (4).
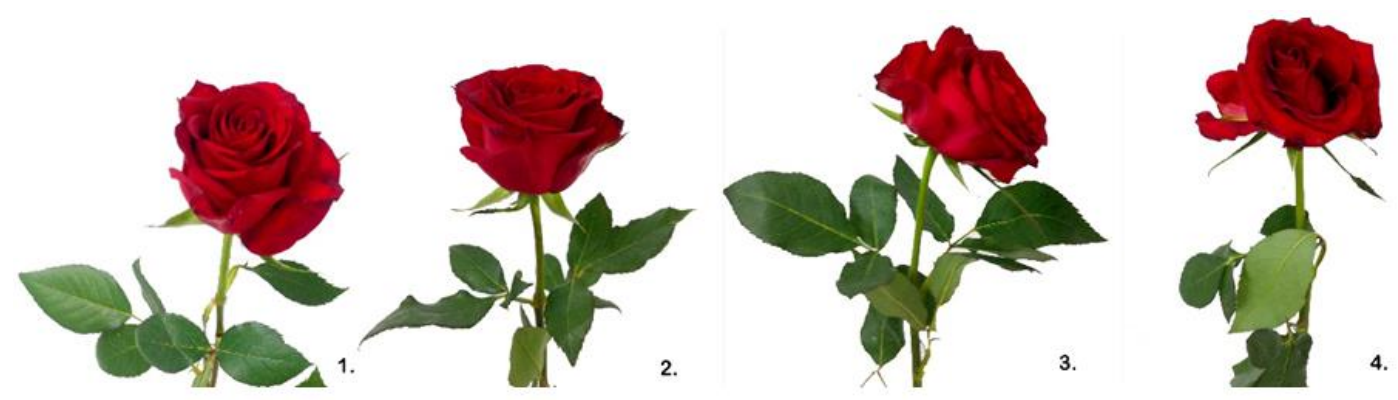

Figure 5. Preestablished notes for the turgescence evaluation. Caption: turgid (1), slightly wilted (2); sharp wilting (3); severe wilting (4).

The standards considered for turgor, evaluated the texture and color of the leaves, if the bud had turgid features and the texture of the petals.

The parameters evaluated in this study are very important for the quality of roses, since the turgescence is necessary for the development of flower buds and for the continuity of the metabolic activity in the cut flower. Darkness may be related to water stress (Paull 1981) or low carbohydrate concentration (Reid 2004) and stems curvature probably occurs due to the presence of bacteria that block xylem vessels and hinder the flow of water (Witte and Van Doorn 1988).

\section{RESULTS AND DISCUSSION}

The criteria chosen for the evaluation of the treatments aimed to determine the longevity and quality factors of the flower stems until the waxing of the decorative life of the flowers.

Temperature. As an aid in maintaining the roses' durability, the experiment was conducted under optimum conditions of storage temperature, in order to allow the analysis of the effectiveness of post-harvest treatments.

Low temperatures are crucial in maintaining cut flowers (Nell 1992), prolonging their pot life, reducing respiration rate and water loss, as well as reducing flower production and sensitivity to ethylene (Fischer 1953; Staby et al. 1976).

Solutions' pH. Measurements of $\mathrm{pH}$ demonstrated that there was an influence of $\mathrm{pH}$ in the maintenance of roses longevity, the treatment "Crhysal complete" (T5) (Table 2) revealed better results and was the only treatment always kept in acid $\mathrm{pH}$ during all the experiment. As a result, there was no vessel obstruction and there was no proliferation of microorganisms in the water, as was the case in the control.

Table 2. pH measurements of the solutions used along the experiment.

\begin{tabular}{cccc}
\hline Treatments & $\mathrm{pH} 1^{\circ}$ water & $\mathrm{pH}$ packa/transp. & $\mathrm{pH}$ test pot \\
\hline 1 & 7.0 & 7.0 & 8.2 \\
2 & 4.7 & 7.0 & 8.2 \\
3 & 4.7 & 3.5 & 8.2 \\
4 & 7.0 & 3.5 & 8.2 \\
5 & 4.7 & 3.5 & 3.2 \\
\hline
\end{tabular}

Obs. $\mathrm{pH} 1^{\circ}$ water: measured from the first basket in which the newly harvested roses were placed. $\mathrm{pH}$ packa/ transp .: measured step 2, packaging and transport ( $2^{\text {nd }}$ treatment). $\mathrm{pH}$ test pot: measured on 09/08, on transfer to test pots (final consumer).

According to Mattiuz et al. (2003) acid solutions can inhibit the action of endogenous enzymes which contribute to block the vessels of floral stems or to inhibit the development of microorganisms. Van Doors and Perik (1990) 
studies corroborate in this sense because they verified that the concentration of $200 \mathrm{mg} \mathrm{L}^{-1}$ of $8-\mathrm{HQC}$ and low pH prevented the block of vessels in four cultivars of roses by the reduction in the number of bacteria in the flower stem. Nowak and Rudnicki (1990) emphasize that the citric acid has a bactericidal action and favors water absorption.

The treatment 3 had a good durability post-harvest when compared to control. This treatment represents the reality practiced by rose producers, which are concerned with doing the post-harvest operations only inside their property, during the stages right after harvest, packaging and transport. However, in the last stage, the water $\mathrm{pH}$ reaches alkaline values, showing visible differences in relation to the flowers that were submitted to the complete treatment (treatment 5).

Turgescence. In the evaluation of the experiment, the roses kept as control (T1), signs of loss of turgescence began on the second day of pot (09/09), reaching severe wilt and loss of decorative life 5 days after the transfer of the stems to the test pots (Figure 6). The roses of Treatments 2, 34 had a satisfactory yield as the turgescence of the stems reaching the severe wilting and the end of the decorative life between 7 and 8 days after transfer of the stems.

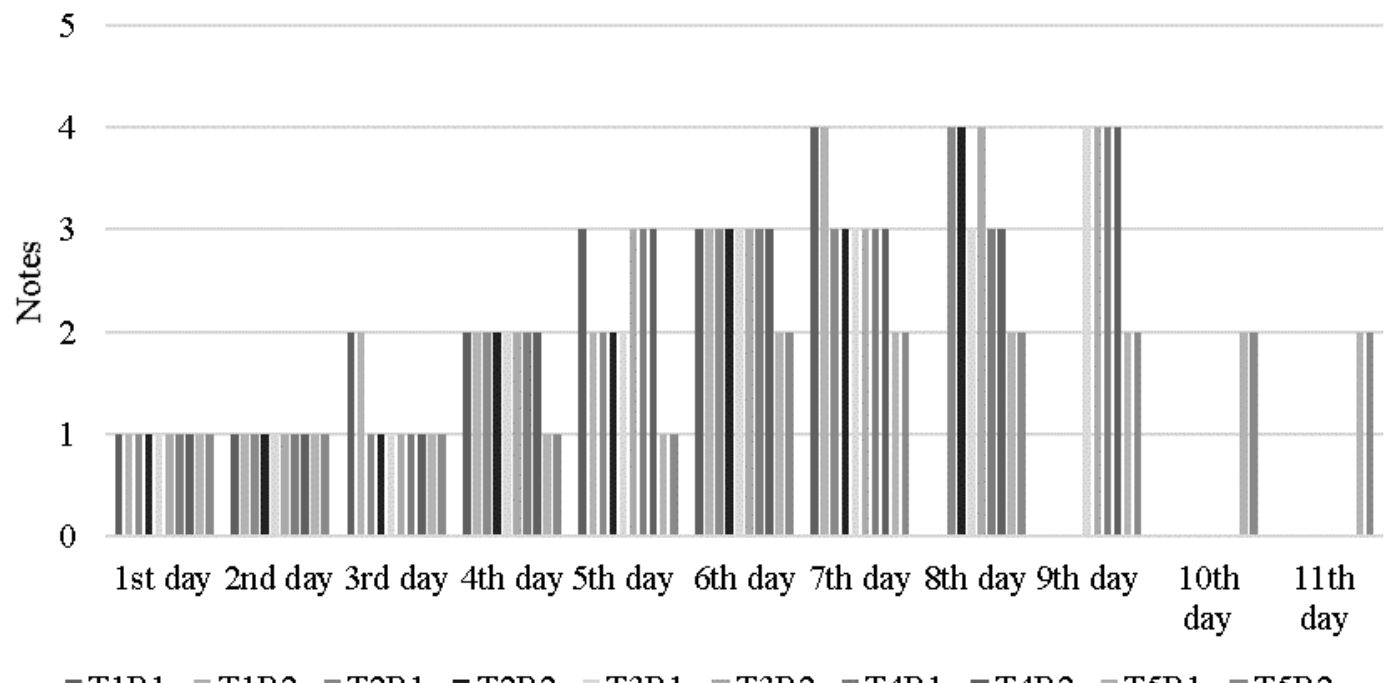

Figure 6. Treatments relation with the flower stems turgescence along the time, according to the preestablished note scale. Caption: (1) turgid, (2) slightly wilted, (3) sharp wilting, (4) severe wilting.

According to Ichimura et al. (2006) the loss of mass may be caused by transpiration, the decrease in absorption of water due to obstruction of vessels by microorganisms or by genetic factors. The authors also explain that for a greater flower longevity, it is necessary to maintain a high level of flowers' fresh mass during the postharvest life.

For Munõz et al. (1982) the turgescence is necessary so that the development of the flower buds occurs until the complete opening of the flowers. Another key factor for the loss of the commercial quality of cut flowers is the vascular blockade caused by microorganisms, which inhibits the supply of water and nutrients to the flowers. This block directly influences the turgescence of the stems, compromising the commercial quality of the roses.

According to Figure 6 , it is observed that the treatment 5, "Chrysal completo" had only signs of mild wilt until the day of the end of the vessel's decorative life. The commercial products used in the treatments of this research have in their composition chemical compounds (citric acid and aluminum sulfate) that lower the $\mathrm{pH}$, contributing to control microorganisms. It was also observed in the formulas chlorinated compounds and sugars.

Different chlorinated formulas have been used with success in roses (Ketsa and Ddaung 2007). Chlorinated compounds, including sodium hypochlorite, calcium hypochlorite and dichloroisocyanuric acid (DICA) are efficient biocides against a large number of bacteria, fungus, algae and viruses, and with common usage in pot solutions, especially in low liberation formulas (Clasen and Edmonson 2006).

The exogenous supply of sugars has been efficient in extending the useful life of the cut flowers, suggesting that the lack of sugars can lead to the wilting of the petals (Van Doorn 2004). On the other hand, sugar accumulation is a mechanism to reduce water potential in petals, promoting water absorption for cell stretching and flower opening, and sucrose can act as an osmotically active molecule that favors water absorption and maintenance of the turgescence of flowers (Hassan 2009). 
Floral opening. Among the visual attributes that most pleases the consumers of cut roses, is the floral opening. This characteristic is closely related to the quality of the stems, sanity and the contents of reserves so that the full opening of the buds occurs.

In relation to flower opening (Figure 7), the treatments 1,2, 3 and 4 already had buds with the beginning of anthesis when being transferred to the test vessels and reach the full opening between the days 09/13 and 09/14. It was counted, considering all the stems of repetitions stems where there was no opening, that is, the stems that have reached the end of decorative life with buds that did not open.

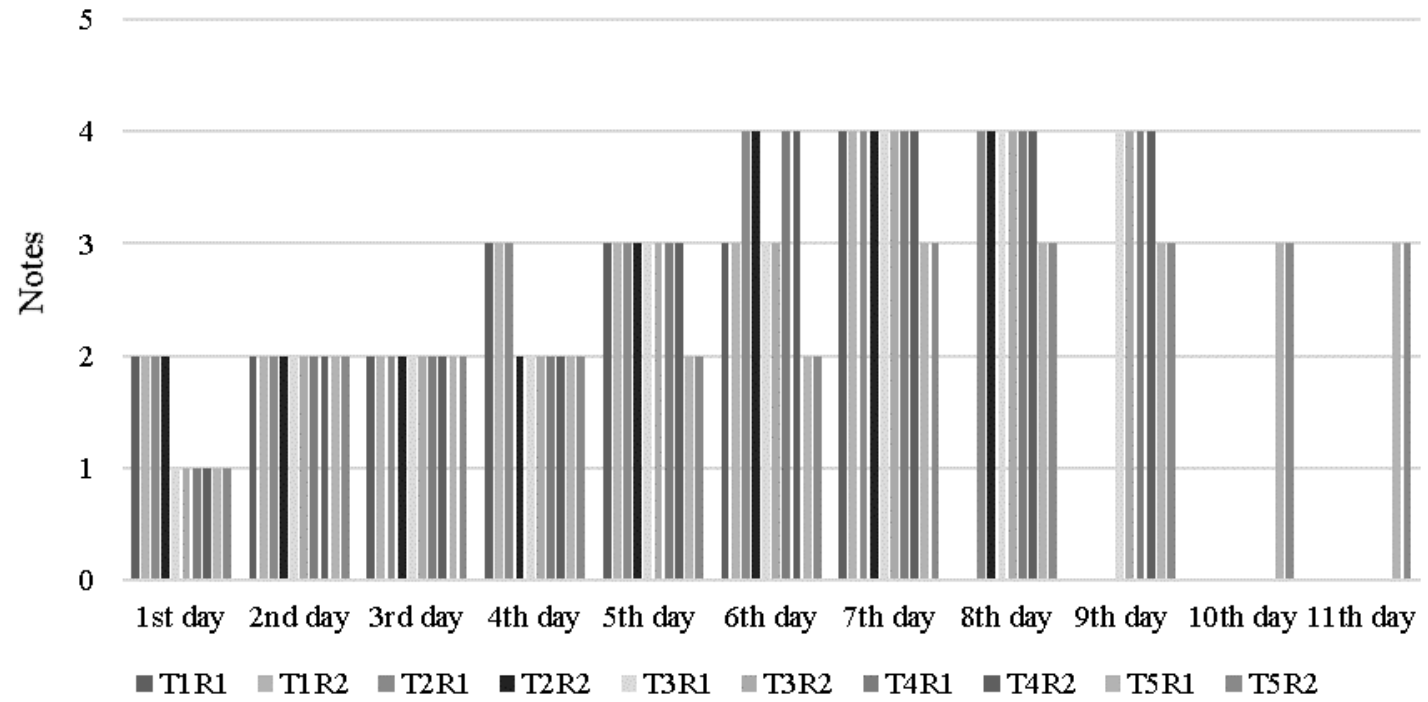

Figure 7. Treatments relation with the flower opening along the time, according to the preestablished note scale. Caption: (1) bud, (2) beginning of anthesis, (3) anthesis, (4) totally open.

Treatment 1 had 3 unopened buds; treatment 2 had 3 unopened buds; treatment 3 had 4 unopened buds; treatment 4 had 2 unopened buds and Treatment 5 , all buds had fully opened (Figure 8 ).

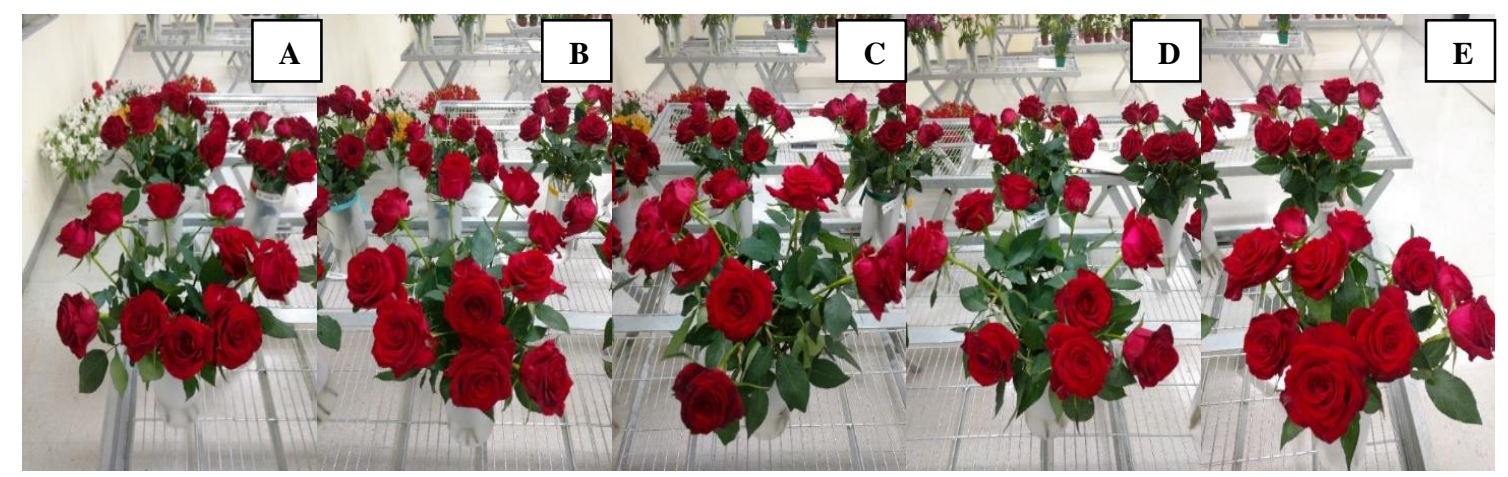

Figure 8. Evaluation of the flower opening of the treatments. Caption: A - Treatment 1, B - Treatment 2 , C - Treatment 3. D - Treatment 4 and E - Treatment 5. Removed from the solution on 09/11.

Observing the figures, as for the floral opening, except for the control, it is noticed that all stems of all treatments are in good conditions, but for the control where can be noticed the tonality of the petals in an opaquer tone.

Darkening of petals. Darkening of petals is also a factor that determines roses quality and durability. In this experiment, all flowers that received any kind of post-harvest treatment, obtained lower rates of darkening of petals.

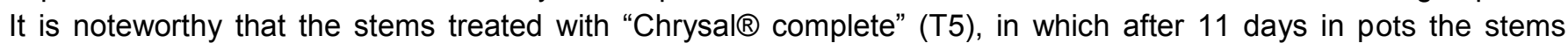
demonstrated darkening only on the last day of analysis (18/09) (Figure 9).

After treatment 5, the treatment 3 had the best parameters as for petals darkening. The petals also darkened completely at the end of pot life (16/09). Treatments 2 and 4, had a satisfactory result as for darkening. Their stems already presented darkened buttons on the sixth day in pot (13/09), being discarded three days later (16/09).

Since beginning, the control always had an opaque color compared to the other treatments. The light darkening began to appear on the first day in pot (08/09) and worsened on the seventh day in pot (09/14), the day of disposal. 


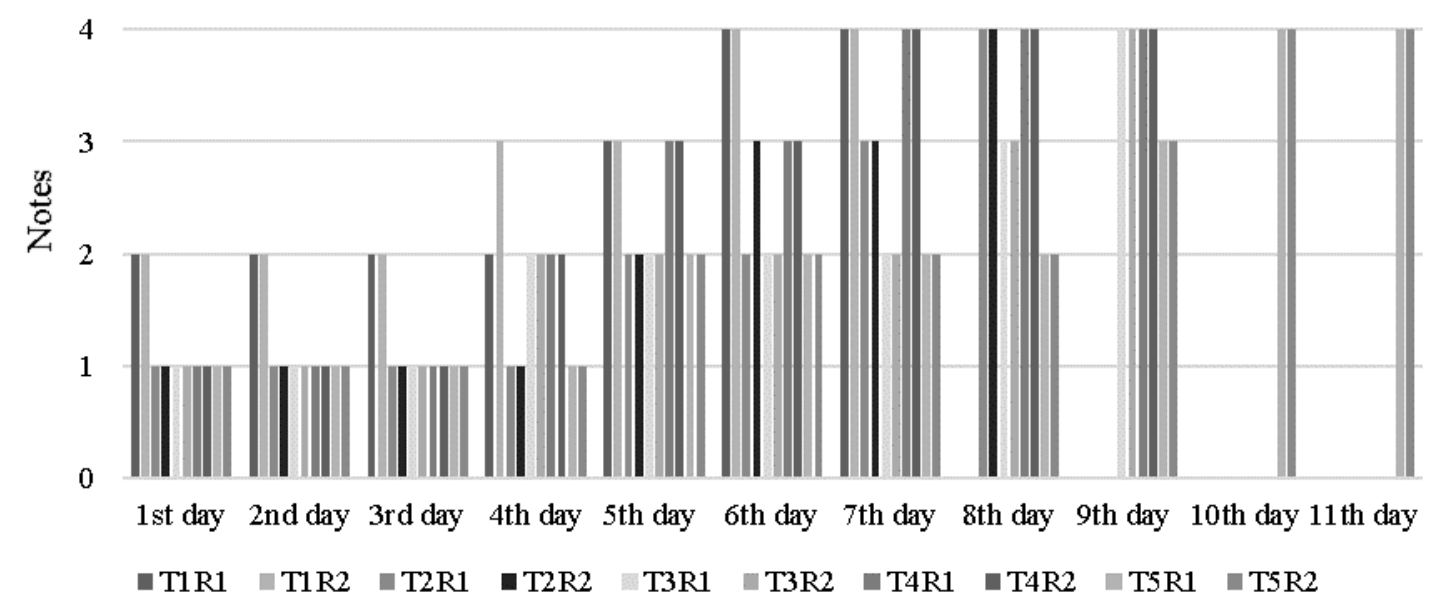

Figure 9. Relationship of the treatments with the darkening of the petals over time, according to the preestablished scale of notes. Caption: no darkening (1), slight darkening (2), moderate darkening (3), darkening intense (4).

Darkening of the petals is a natural process of senescence of the stems, and may be more pronounced in the case of flowers with red coloration, due to the higher content of anthocyanins. Anthocyanins are water-soluble pigments responsible for the red color of flowers, fruits and plants. They are unstable compounds that undergo discoloration by the action of enzyme systems, and by the presence of oxygen. The decomposition is affected by temperature, $\mathrm{pH}$, the presence of other phenolic compounds, sugars and their degradation products, ascorbic acid, light and metal ions. (Chitarra and Chitarra 2005).

The use of preservative solutions may delay this process, as was observed in Treatment 5 (Chrysal ${ }^{8}$ completo), the stems reached intense blackness on the last day of evaluation and began to show slight signs of darkening in the petals only on the fifth day of pot life (12/09). From the earliest days of the vessel, the witness had the petals slightly darkened, reaching intense darkening rapidly on the seventh day of vessel life (14/09).

Bent Neck. Bent Neck manifests by the deposition of organic compounds in the in the lumen of xylem vessels or by the exudation of latex (Finger et al. 2003), the growth of microorganisms or the formation of air bubbles.

The manifestation of stems with Bent Neck, represents the disuse of these for the commercialization. In the experiment, all treatments had fallen stems and total tipping at the end of the decorative life, except for treatment 5 , in which the stems remained upright throughout the treatment and no stem with curvature was counted (Figure 10).

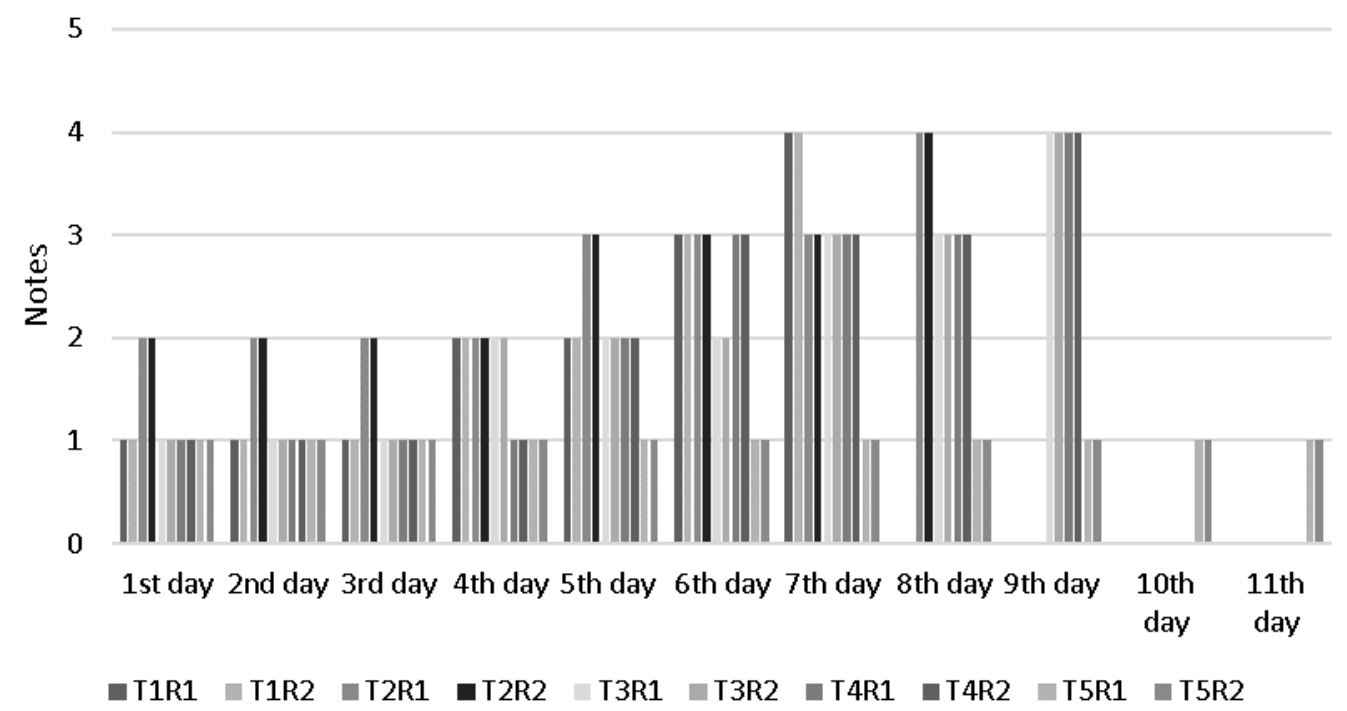

Figure 10. Relation of treatments with Bent-Neck along the period, according to preestablished note scale. Caption: without curvature (1), begin of curvature (2), medium curvature (3), tipping (4). 
In the figure above, it is possible to observe the maintenance of stems without curvature in the T5. The stems of treatment 2 had a lower yield than the control, since the stems manifested curvature at the beginning of pot life. On the fifth day in pot were counted 3 stems fallen, one of them already with severe curvature. Yet, in the control, the beginning of the curvature occurred on the sixth day in pot.

In the control, the results have been excellent from the beginning for treatments compared to T2, T3 and T4, because not having any post-harvest treatment and staying with quality in the initial days, similar to the other treatments. On the other hand, contrary to treatments T2, T3 and T4, the velocity in which the control starts to disintegrate and finishes its pot life is way faster.

The first stems with curvature onset were noted on the fifth day in pot (09/12). On the sixth day an evolution to medium curvature (09/13) was already verified, and on the seventh day in the pot were already completely curved, requiring discarding. Pietro et al. (2012) verified that roses cv. Veja kept in the treatment, only with distilled water presented an intense petal darkening, withering and a high Bent Neck rate in the majority of the evaluated stems. The treatments T3 and T4 had, on average, during the experiments, 4 stems with medium curvature up to the 5th day in pot. Falling completely on the day of discard, 16/09.

The reason why the treatment 5 presented no Bent Neck during all the experiment may be explained due to the storage of the stems in an acidified medium, with clean water free of microorganisms and with a supply of carbohydrates. All other treatments had, at least, one stage where the stems were stored in clean water with low $\mathrm{pH}$ and good energy supply, yet, $\mathrm{T} 1$ remained during all the experiment in water with low $\mathrm{pH}$ and low energy supply.

Fresh mass evaluation. Figure 11 has the values of fresh mass accumulated over the evaluation period by means of regression equations of each treatment.

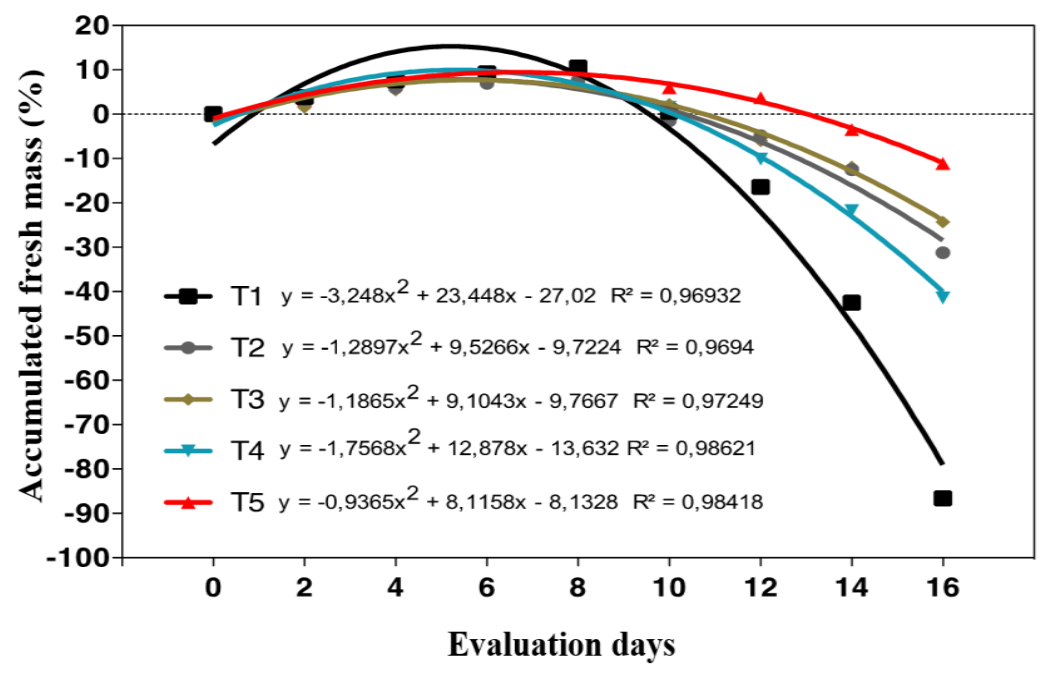

Figure 11. Accumulated variation of roses' fresh mass cv Ipanema submitted to 5 treatments after harvest.

The loss of fresh mass of the inflorescences of roses cv. Ipanema varied during the days of pot life, among the treatments performed. The variation of accumulated fresh mass of the flowers was higher for the control treatment $(-89,59 \%)$, followed by the treatments $4(-41,18 \%), 2(-31,23 \%)$ and $3(-24,30 \%)$. Treatment 5 presented the smallest loss $(-11,13 \%)$ of fresh mass accumulated during the period, standing out from the others. It is important to emphasize that this treatment was the most complete, once it had conservation solutions during all stages postharvest. This result highlights the importance of using adequate conserving solutions in the post-harvest of cut flowers because they provide a favorable hydric balance, resulting in increased turgidity, floral opening and reduction of senescence factors.

The loss of fresh mass of cut flowers may be because of a vascular blockage of the xylem vessels, and in this case perspiration in the stems continues to occur, which leads to a loss of water from the flowers and leaves due to lower water potential of the stem (Van Doorn 1997). This is, with the blockage of the conducting vessels, there is the development of a negative water balance, since the rate of water absorption is lower than the transpiration rate (Van Meeteren et al. 2006).

Absorption and water quality. As to water absorption, at Table 3 it can be observed the amount of water in the test pots, considering the first pot day (09/08) and the fourteenth pot day, corresponding to the final analysis. 
Table 3. Values measured according to the remaining water from the test pots.

\begin{tabular}{ccc}
\hline \multirow{2}{*}{ Treatment } & \multicolumn{2}{c}{ Day } \\
\cline { 2 - 3 } & Sep 8th & Sep 18th \\
\hline T1 & $1,000 \mathrm{~mL}$ & $960 \mathrm{~mL}$ \\
T2 & $1,000 \mathrm{~mL}$ & $905 \mathrm{~mL}$ \\
T3 & $1,000 \mathrm{~mL}$ & $637 \mathrm{~mL}$ \\
T4 & $1,000 \mathrm{~mL}$ & $594 \mathrm{~mL}$ \\
T5 & $1,000 \mathrm{~mL}$ & $440 \mathrm{~mL}$ \\
\hline
\end{tabular}

There was a more expressive water absorption in the treatment 5 when compared to the other treatments, followed by T4, T3, T2 and T1. In rose cv. Vega it was observed that the treatments with 8-hydroxyquinoline and citric acid (acid $\mathrm{pH}$ ) were the most promising to keep the quality and prolong the flower's pot life, contributing to a low loss of fresh mass, low respiratory activity and relative water content; better maintenance of soluble and reducers carbohydrates, anthocyanin and coloring (Pietro et al. 2012).

Botrytis incidence. One of the most common problems with conservation of roses during the post-harvest period is the contamination by the fungus Botrytis cinerea. Its symptomatology is characterized by petal necrosis and, in some cases, in the stems, with mycelial growth and a typical brown-gray mass of spores (Caldari et al. 1997).

Considering this, during the evaluation days it was observed that until 09/11 (4th in pot) several foci of $B$. cinerea were observed in all the experiments. However, what differentiated the treatments during the visual evaluations was the fungus attack severity, completely deteriorating some flowers and in others it manifested inexpressively. In the control it was observed in $09 / 13$ ( $6^{\text {th }}$ day in pot), eight stems with $B$. cinerea in advanced deterioration stage.

In general, the experiment was positive in relation to the incidence of $B$. cinerea, not occurring significant losses during pot life. No stems in advanced stage were found in T5, the only focus, and until the end of the experiment there was no evolution of symptoms to a more critical state.

The post-harvest storage environment contributes to the fungus proliferation if temperatures and relative humidity are favorable. In the test center the temperature is always milder and with low relative humidity, contributing to inhibit the development of the fungus. As well as the stems with better post-harvest quality (T5) because they were kept in preservative solutions for a longer time, they did not have a significant incidence of this fungus.

It was concluded that treatment 5, "Chrysal ${ }^{\circledR}$ completo" (Chrysal@ Primer + Chrysal Professional 2 T-bag ${ }^{\circledR}+$ Chrysal Universal Clear $($ ), allowed for better quality and longer longevity of the cv. Ipanema; evidenced by the greater turgescence of the stems during the experiment, greater floral opening, smaller darkening of petals, lower incidence of Bent Neck and less loss of fresh mass.

\section{References}

Caldari JRP et al. 1997. Doenças das Plantas Ornamentais. Manual de Fitopatologia: Doenças das Plantas Cultivadas. São Paulo: Ceres. pp.549-570.

Castro CEF. 1993. Heliconias como flores de corte: Adequação de espécies e tecnologia pós-colheita. Tese (Doutorado). Piracicaba: USP.

Chitarra MIF and Chitarra AB. 2005. Pós-colheita de frutos e hortaliças: fisiologia e manuseio. Lavras: ESAL/FAEPE.

Clasen T and Edmonson P. 2006. Sodium dichloroisocyanurate ( $\mathrm{NaCCC}$ ) tablets as an alternative to sodium hypochlorite for ten routine treatments of drinking water at the household level. International Journal of Hygiene and Environmental Health 209:173-181.

Diastagliacozzo GM and Castro CEF. 2002. Fisiologia da pós-colheita de espécies ornamentais. In: Wachowicz CM and Carvalho RIN (Org.).

Fisiologia vegetal: produção e pós-colheita. Curitiba: Champagnat. pp.359-382.

Finger FL et al. 2003. Colheita, classificação e armazenamento de inflorescências de crisântemos. In: Barbosa JG. Crisântemos. Viçosa: Aprenda Fácil. pp.123-140.

Fischer CW. 1953. Long-term holding of cut flowers. Proceedings of the American Society for Horticultural Science 61:585-592.

Halevy AH and Mayak S. 1974. Improvement of cut flower quality opening and longevity by pre-shipment treatments. Acta Horticulturae 43:335347.

Hardenburg RE et al. 1990. The commercial storage of fruits, vegetables and florist and nursey stocks. Agricultural Handbook 66, 130p.

Hassan FAS. 2009. Influence of 8-hydroxyquinoline sulphate and sucrose treatments on the post-harvest quality of cut flowers of Strelitzia reginae and Hippeastrum vittatum. Acta Agronomica Hungarica 57:165-174.

Ichimura K et al. 2006. Extension of the Vase Life in Cut Roses by Treatment with Glucose, Isothiazolinonic Germicide, Citric Acid and Aluminum Sulphate Solution. Japan Agricultural Research Quarterly 40:263-269.

Ketsa S and Dadaung S. 2007. Effects of sodium dichloroisocyanurate and sucrose on vase life of cut roses. Acta Horticulturae 751:465-472.

Macnish AJ et al. 2010. Genotypic variation in postharvest performance and ethylene sensivity of cut rose flowers. Hortscience 45:790-796.

Mattiuz CFM. et al. 2003. Armazenamento refrigerado de inflorescências cortadas de Oncidium varisosum 'Samurai'. Ciência Rural 40:22882293. 
Munõz CE et al. 1982. Hydraulic conductivity and ethylene production in detached flowering peach shoots. HortScience 17:226-228.

Nell TA. 1992. When it comes to storing flowers, it pays to be cool. FloraCulture International 1992:4-5.

Nowak J and Rudnicki RM. 1990. Postharvest handling and storage of cut flowers, florist greens and potted plants. Timber Press: Portland.

Oliveira MJG. 1995. Manual sobre Pós-Colheita de rosas. Holambra- São Paulo. Veiling Holambra. 42p.

Paull RE. 1981. Temperature-induced leakage from chilling-sensitive and chilling-resistant plants. Plant Physiology 68:149-153.

Pietro J et al. 2012. Manutenção da qualidade de rosas cortadas cv. Vega em soluções conservantes. Horticultura Brasileira 30:64-70.

Reid M. 2004. Rose, spray rose, sweetheart rose: recommendations for maintaining postharvest quality. Postharvest technology research and information center. University of California.

Rogers HJ. 2006. Programmed cell death in floral organs: how and why do flowers die? Annals of Botany 97:309-315.

Siegelman HW. 1952. The respiration of rose and gardenia flowers. Proceedings of the American Society for Horticultural Science 59:496-500.

Staby GL et al. 1976. Proc. Natl. Floricultural Conf. On Commod. Handling. Ohio State University. Dept. Hort., Hort. Ser. 432, 7lp.

Van Doorn WG, Perik RRJ. 1990. Hydroxyquinoline citrate and low pH prevent vascular blockage in stems of cut rose flowers by reducing the number of bacteria. Journal of the American Society for Horticultural Science 115:979-981.

Van Doorn WG. 1997. Water relations of cut flowers. Horticultural Reviews 18:1-85.

Van Doorn WG. 2004. Is petal senescence due to sugar starvation? Plant Physiology 134:35-42.

Van Meeteren $U$ et al. 2006. Inhibition of water uptake after dry storage of cut flowers: Role of aspired and wound-induced processes in Crysanthemum. Postharvest Biology and Technology 41:70- 77.

Witte Y, Van Doorn W. 1988. Identification of bacteria in the vase water of roses and the effect of isolated strains on water uptake. Scientia Horiculturae 35:285-291.

Woltering EJ, Van Doom WG. 1988. Role of ethylene in senescence of petals - morphological and taxonomic relationships. Journal of Experimental Botany 39:1605-1616.

Zieslin N andGottesman V. 1983. Involvement of ethylene in the abscission of flowers and petals of Leptospermum scoparium. Physiologia Plantarum 58:114-118. 